\author{
MONIKA SKRZESZEWSKA
}

Uniwersytet Jagielloński, Kraków

\title{
„MJEŠAVINU USPITE” LUB „MEŠAVINU SIPAJTE” — CZY TLUMACZENIA I ODDZIELNE INSTRUKCJE KONSUMENCKIE NA OBSZARZE BYLEGO JĘZYKA SERBSKO-CHORWACKIEGO SĄ POTRZEBNE? ANALIZA WYBRANYCH PRZYKLADÓW
}

Słow a kluc zow e: język serbsko-chorwacki, język bośniacki, język chorwacki, język czarnogórski, język serbski.

\section{STRESZCZENIE}

Artykuł przedstawia i analizuje różnice językowe w obrębie obszaru byłej Jugosławii. Polityka językowa państw postjugosłowiańskich ma na celu udowodnienie różnic występujących pomiędzy językami tych państw, dlatego podjęte badania, na podstawie przykładu thumaczenia z chorwackiego na serbski oraz etykiet produktów spożywczych, chcą udowodnić, że są one symboliczne. Cztery języki powstałe z języka serbsko-chorwackiego wciąż opierają się na nowosztokawskim dialekcie, stąd odmienności dostrzegalne są przede wszystkim na płaszczyźnie leksykalnej właściwej dla danego regionu, nie narodu. Wyniki analizy wybranych przykładów pokazują, że różnice te próbuje się sztucznie uwypuklić, ponieważ często zamieniane leksemy są właściwe dla obu języków, nie tylko dla jednego. Przy analizie zastosowano metodę komparatystyczną.

\section{WPROWADZENIE — OD JEDNEGO DO CZTERECH JĘZYKÓW?}

Za genezę wspólnego języka literackiego uznaje się zjazd intelektualistów chorwackich i serbskich w Wiedniu w 1850 roku, podczas którego podpisano tzw. umowę wiedeńską (Bečki književni dogovor). Jego podstawą był, proponowany przez etnologa serbskiego Vuka Stefanovicia Karadžicia (1787-1864), nowosztokawski wariant wschodniohercegowiński w wymowie ijekawskiej, posiadający największy zasięg terytorialny oraz etniczny (Bońkowski 2010: 27-28). Jak wskazuje np. Maria Cichońska, umowa ta była zlepkiem języków czterech narodów: Chorwatów, Czarnogórców, muzułmańskich mieszkańców Bośni i Hercegowiny ${ }^{1}$ oraz Serbów, dlatego jeden standard został „nałożony” na zróżnicowany językowo obszar (Cichońska 1994: 43-44). Przyczyniło

\footnotetext{
${ }^{1}$ W 1971 roku zostali oni uznani za naród i od tej pory Muzułmanin pisany wielką literą określał członka narodowości. W 1993 roku nazwę tę zamieniono na Boszniak (Bošnjak), podczas gdy Bośniak to obywatel Bośni i Hercegowiny bez względu na narodowość.
} 
się to ostatecznie do niepowodzenia tego projektu, ale należy zaznaczyć również, że w większości nie przestrzegano założeń porozumienia wiedeńskiego.

$\mathrm{Na}$ terenach chorwackich występowała trójdialektyczność (tronarječnost) $)^{2}-$ dialekty czakawski, kajkawski i sztokawski, a także trójalfabetyczność (tropismenost) głagolica, cyrylica oraz łacinka. Kodyfikację języka chorwackiego na podstawie sztokawszczyzny rozpoczęto jeszcze na przełomie XVI i XVII wieku, ale zintensyfikowane działania wiążą się z latami 30. XIX wieku, w czasach odrodzenia narodowego, zwanego iliryzmem. Zakładał on szersze zjednoczenie Słowiańszczyzny południowej z Serbami, Słoweńcami, a nawet z Bułgarami, np. w ramach tzw. języka ilirskiego. Pod koniec XIX wieku jako podstawę literackiego języka chorwackiego przyjęto wariant i zasady wypracowane przez Vuka Karadžicia, co kontynuowało założenia zjednoczeniowe np. z Serbami. Dokonano tego za pośrednictwem tzw. chorwackich Vukowców (jedna z czterech szkół filologicznych przedstawiających propozycję kodyfikacji języka chorwackiego), którzy oskarżani byli o zubożenie bogactwa językowego Chorwacji, np. ze względu na ograniczenie tradycji regionalnych, czy przystosowanie niektórych zasad morfologicznych do gwary ludowej, typowej dla idiomu serbskiego. Zatem od idei wspólnego języka do rzeczywistej jej realizacji w Chorwacji upłynęło około pięćdziesięciu lat, choć już kilka lat po przyjęciu standardu Karadžicia zaczęto go negować (zob. więcej: Oczkowa 2011: 294-295, 309-310).

Ciekawym przypadkiem jest sama Serbia, która paradoksalnie nie przyjęła reformy swojego uczonego (oprócz norm ortograficznych w 1868 roku). Narzecze wschodniohercegowińskie swoim zasięgiem nie obejmuje północno-centralnej Serbii (Szumadija) oraz Wojwodiny (występuje tylko w zachodniej części państwa serbskiego). Tereny te w XIX wieku miały wykształconą tradycję piśmienniczą, opartą na dialekcie szumadijsko-wojwodińskim w wymowie ekawskiej (do dziś jest to podstawa dla serbskiego języka literackiego) (Popiołek 2011a: 259; Paždjerski, Chacia 2014: 28-29).

Wielu badaczy zaznacza także, że umowa wiedeńska ominęła język muzułmańskich mieszkańców Bośni i Hercegowiny. Agnieszka Hofman-Pianka pisze:

Fakt, że język stworzony przez Vuka Karadžicia ma za podstawę dialekt wschodniohercegowiński thumaczy opory w jego przyjmowaniu [...]. Całkowicie słuszne wydają się w tej sytuacji protesty Bośniaków z powodu nieuwzględniania bośniackiego elementu etnicznego w nazwie języka opartego na dialekcie występującym na dużej części zajmowanego przez nich terytorium (Hofman-Pianka 2000: 60-61).

Po stronie czarnogórskiej odnajdziemy z kolei inne, choć nierzadko niespójne, argumenty. Na przykład Przemysław Brom zauważa: „Nie dziwi zatem fakt, iż na obszarze czarnogórskim reforma Karadžicia przyjęta została bez większego oporu — Czarnogórcy od wieków posługiwali się już tym językiem”, a z drugiej strony uważa, co następuje: „Rozpoczyna się systematyczny proces sprowadzania elementów rdzennie czarnogórskich do roli prowincjonalizmów i dialektyzmów, a następnie ich eliminacji z użycia w języku literackim" (Brom 2007: 81-82). Mowa tu o starosztokawskim dia-

\footnotetext{
${ }^{2}$ Można spotkać się również z określeniem „trójjęzyczność” (trojezičnost).
} 
leckie zeckim, do którego dziś próbuje się wrócić. Zresztą oficjalna norma językowa z 2009 roku odwoluje się do tej tradycji, uznanej przez jedną grupę lingwistów za immamentnie czarnogórską (Popiołek 2011b: 275).

Jakim tworem lingwistycznym był język serbsko-chorwacki? Spór ten jest nierozstrzygalny, po każdej stronie bowiem formułowane są liczne argumenty i kontrargumenty potwierdzające bądź negujące dane stanowisko. Przyjmując koncepcję Henryka Jaroszewicza i Snježany Kordić, można uznać, że dominują trzy argumentacje. Po pierwsze, serbsko-chorwacki stanowił język homogeniczny (kryterium genetyczne) (Jaroszewicz 2004: 30-36). Po drugie, był językiem wariantywnym lub semistandarowym (kryterium socjolingwistyczne). Poprzez wariantywność możemy rozumieć, że język serbskochorwacki to język policentryczny (policentrični standardni jezik), łączący w sobie pierwiastki bośniackie (muzułmańskie), chorwackie, czarnogórskie lub serbskie (Kordić 2010: 47-48). Czasem też serbsko-chorwacki określa się jako język dwuwariantywny chorwacki i serbski. Wiąże się z tym semistandardowość, która została przyjęta na mocy konstytucji Chorwacji z 1974 roku. Takie stanowisko odseparowało od siebie języki chorwacki i serbski, uznając je za dwa oddzielne warianty, a nie jako jeden zróżnicowany wewnętrznie język. Po trzecie, język serbsko-chorwacki to twór sztuczny stworzony na potrzeby polityczne (zjednoczenie w jednym państwie jugosłowiańskim ${ }^{3}$ ), stąd zasadność „rozwodu językowego” (kryterium wartościujące) (Jaroszewicz 2004: 44-45).

Komplementarna w kilku punktach, ale także i znacząco uzupełniająca jest klasyfikacja dokonana przez Agnieszkę Spagińską-Pruszak. Nawiązując do homogeniczności (pierwsze stanowisko z poprzedniego akapitu), wspomniana badaczka uznaje, że to jeden język używany przez Boszniaków, Chorwatów, Czarnogórców i Serbów, choć stanowi on źródło wzajemnego bogactwa językowego, nie tworząc tym samym jednorodnego standardu. Wariantywność (drugie stanowisko) rozumie podobnie jako cztery równoprawne warianty — boszniacki, chorwacki, czarnogórski i serbski — jednego języka, z zaznaczeniem jednak występowania napięcia pomiędzy chorwackim a serbskim kodem, które neutralizuje wariant boszniacki i czarnogórski. Dwuwariantywność (drugie stanowisko) oznacza występowanie wersji chorwackiej (zagrzebskiej, zachodniej) oraz serbskiej (belgradzkiej, wschodniej), wyróżniających się cechami samodzielnych standardów językowych. Semistandardowość (drugie stanowisko) z kolei traktuje tak samo, podkreślając, że takie zdanie akcentują przede wszystkim językoznawcy chorwaccy (innymi słowy, to twierdzenie pozostaje żywe od oficjalnego uznania odrębności języka chorwackiego w 1974 roku), rzadziej serbscy. Ostatni głos wskazujący na sztuczność języka serbsko-chorwackiego znalazł się również w klasyfikacji Spagińskiej-Pruszak. Oznacza to zatem, że funkcjonują cztery równoprawne języki, a pod uwagę należy wziąć nie tylko kryterium wartościujące, ale także socjolingwistyczne (Bońkowski 2010: 39-41). Uwzględniając dwa powyższe akapity odpowiedź na postawione pytanie jest najpełniejsza.

\footnotetext{
${ }^{3} \mathrm{~W}$ okresie titowskiej Jugosławii w imię dewizy „,braterstwa i jedności” zakładano, co prawda, równoprawność narodów, ale jednocześnie dążono do wykształcenia tożsamości jugosłowiańskiej (tzw. homo jugoslavicus).
} 
Jednakże użyta przeze mnie w tytule syntagma ,były język serbsko-chorwacki” implikuje przyjęcie tezy, w myśl której istniał wspólny kod językowy dla Chorwatów i Serbów, też dla Bośniaków i Czarnogórców. W wyniku pewnych okoliczności uległ on rozpadowi na cztery odrębne języki narodowe. Warto jednak zwrócić uwagę na fakt, że języki te wciąż łączy nowosztokawska baza lingwistyczna. Otwiera to realne możliwości wzajemnego zrozumienia w komunikacji. Tak jak w czasach jugosłowiańskich, kiedy dla 75\% obywateli (w 1981 roku) pełnił funkcję lingua communis (Požgaj Hadži, Balazić Bulc, Miheljak 2013: 39), tak i współcześnie jest kodem komunikacyjnym. Nazewnictwo zatem jest czymś innym niż faktycznie istniejący język.

Uznanie konstytucyjne tych czterech języków np. zakłada konieczność funkcjonowania odrębnych kierunków akademickich, czy otwiera spór o literaturę uznawaną do 1991 roku za wspólną, tj. jugosłowiańską, a dokładniej o narodowość pisarzy (modelowym przykładem jest Ivo Andrić ${ }^{4}$ ). W związku z takim stanem rzeczy praktykuje się też działalność translatorską np. z chorwackiego na serbski lub zamieszcza się na produktach spożywczych odrębne językowo instrukcje konsumenckie, co jest przedmiotem podjętej analizy. W większości przypadków są to sytuacje groteskowe, ponieważ różnice między bośniackim, chorwackim, czarnogórskim oraz serbskim są symboliczne, przez fakt o czym była już mowa - że opierają się na jednym systemie nowosztokawskim. Jak zauważa Joanna Rapacka: ,niskość bariery językowej częściej bywała tu przekleństwem niż błogosławieństwem, nie tyle zbliżała, ile utrudniała rozgraniczenie, co stanowiło dodatkowy czynnik konfliktogenny" (Rapacka 1997: 47-48). To dlatego z jednej strony próbuje się zakwestionować bliskość językową (Chorwacja oraz Czarnogóra), a z drugiej strony dochodzi do swoistego „wchłonięcia” języków (np. czarnogórskiego w przypadku serbskim) czy neguje się odrębność językową (np. języka bośniackiego).

\section{TŁUMACZENIA}

W latach 90. XX wieku w chorwackiej przestrzeni publicznej dokonywano tzw. ,duchowej odnowy” (duhovna odnova) (Zieliński 2006: 61), czyli „naprawiania szkód minionego okresu” (Oczkowa 2003: 154). Innymi słowy, była to „rekroatyzacja” (dekroatiziranje) dziedzictwa historycznego poprzez zanegowanie pierwiastków jugosłowiańskich, bałkańskich i serbskich, a głównym narzędziem tej polityki stał się język (Kordić 2010: 17, 27). Polityka purystyczna była jednak zabiegiem niekontrolowanym przez żadną instytucję, ale przede wszystkim niezależna od rodzimych użytkowników języka chorwackiego. Próbowano, często nieskutecznie, odtwarzać archaizmy, promować neologizmy, przeważnie niezrozumiałe dla Chorwatów, w związku z tym ,nowy, ale wirtualny" chorwacki był — w ocenie przeciwników takiej polityki — językiem

\footnotetext{
${ }^{4}$ Mowa tu o tzw. „literaturze pogranicza”, kiedy pisarze deklarują mieszane pochodzenie. Sam Ivo Andrić urodził się w rodzinie chorwackiej w Bośni i Hercegowinie, dlatego uznawany jest za pisarza chorwackiego bądź bośniackiego. Fakt, że po I wojnie światowej wybrał status pisarza jugosłowiańskiego, decydując się na ekawski wariant wspólnego języka, dla wielu Serbów jest argumentem, iż był on pisarzem serbskim. Spór jest nierozstrzygalny, czasami również przenosi się na szczebel sądowy.
} 
„nieprawdziwym” (Vladimir Anić), a nawet wariantem „turbo-chorwackim” (Ivo Pranjković) (zob. więcej: Czerwiński 2005: 76-77). Higiena językowa, kontynuowana w niektórych środowiskach i dziś, służy głównie zanegowaniu faktu istnienia języka serbsko-chorwackiego, dlatego pewni lingwiści chorwaccy wciąż usuwają z ,odzyskiwanego" języka chorwackiego serbizmy bądź internacjonalizmy, zastępując je licznymi neologizmami ${ }^{5}$. Jednakże nigdy nie sprecyzowano pojęcia serbizam, dlatego błędnie uznano za nie m.in. turcyzmy. „Językowe alergie i fobie” służyły i wciąż służą przede wszystkim uprawomocnieniu i podkreśleniu swojej odmienności (Bobrownicka 2006: 217-218). W związku z taką polityką usuwano z bibliotek i księgarń wszystkie pozycje zawierające określenie hrvatski uh sprski lub hrvatskosrpski jezik, a także te wydrukowane w cyrylicy (Jaroszewicz 2004: 147-148). Pod koniec lat 90. XX wieku zaczęto jednak stopniowo udostępniać publiczności chorwackiej m.in. serbskie filmy. Pierwszym był Rane Srđana Dragojevicia, którego tytuł został przetłumaczony na chorwacki -Ozljede, a jego emisji towarzyszyły napisy chorwackie.

Odmienność języka chorwackiego i serbskiego, do której tak bardzo dążą Chorwaci, można odnaleźć na wszystkich płaszczyznach języka: fonetyka (ijekawica-ekawica, np. mlijeko-mleko ${ }^{6}$, czy wymiana głosek lub spółgłosek m.in. t-ć: sretan-srećan), fleksja, słowotwórstwo (w tym np. odmienne sufiksy czasownikowe), składnia (m.in. język serbski, który należy do tzw. ligi bałkańskiej, stąd forma $d a+$ praesens), stylistyka, czy ortografia (np. zapis czasu przeszłego). W języku serbskim dochodzi do kontaminacji, tzn. zrośnięcia członu charakterystycznego dla czasu przeszłego np. imaću dla pierwszej osoby liczby pojedynczej czy imaćemo dla drugiej liczby mnogiej (bezokolicznik imati); w języku chorwackim zapisywane jest to oddzielne: imat ću lub imat ćemo). Najliczniej jednak różnice występują na poziomie leksykalnym (np. povijest-istorija) (Tąporowska 2006: 54-57).

Jednak w przypadku filmu serbskiego Rane potrzeba tłumaczenia okazała się wątpliwa, mimo że w obrazie bohaterowie posługiwali się slangiem belgradzkim. Przede wszystkim dlatego, że wypowiedzi typu: „Vežite se, polećemo” „przetłumaczono” na „Vežite se, polijećemo”, tzn. zmieniono tylko ekawicę na ijekawicę. Można to uznać za szczegół, ponieważ bez tego zabiegu wyrażenie nadal byłoby całkowicie zrozumiałe dla odbiorców chorwackich. Napisy chorwackie wywoływały u widzów uśmiech, a paradoksalnie nawet oryginalny dźwięk serbski był bardziej zrozumiały dla Chorwatów niż przekład chorwacki (Bugarski 2005: 174). Potwierdzają to także słowa pisarza chorwackiego Miljenko Jergovicia ${ }^{7}$, który nazywa tłumaczenie filmu serbskiego ,pierw-

\footnotetext{
${ }^{5} \mathrm{Na}$ przykład w miejsce daljinski upravljač (pilot) proponuje się nową formę daljinac czy zamiast kontejner (kontener) - smećnjak. W związku z tym na wielu forach można odnaleźć wypowiedzi Chorwatów typu: ,pa ja novi hrvatski jedva i razumijem”.

${ }^{6}$ Mowa tu o fonemie jać. Pochodzi on z języka prasłowiańskiego, który fonetycznie oznaczany jest jako ě. W języku serbsko-chorwackim w dialektach ekawskich oznacza „e”, ikawskich „,i”, a w ijekawskich „ije” (tzw. długa jać) lub ,je” (krótka jać).

${ }^{7}$ Miljenko Jergović jest Chorwatem urodzonym i wychowanym w stolicy Bośni i Hercegowiny Sarajewie. W związku z rozpadem wspólnego języka i procesem „odzyskiwania” pisarzy za kryteria uznano m.in. pochodzenie, stąd Jergović raz określany jest jako pisarz chorwacki (ze względu na pochodzenie), a raz jako bośniacki (przez wzgląd na miejsce urodzenia).
} 
szym praktycznym eksperymentem w rozgraniczeniu języka serbskiego od chorwackiego”. Według Jergovicia „test” ten był absurdalny, ponieważ w napisach chorwackich słowa zrozumiałe zastąpiono nieużywanymi bądź znanymi wąskiej grupie użytkowników odpowiednikami:

Srbin nam s plata veli „svi su se ložili na rat”, što je, priznat ćete, fraza koja je razumljiva svima od Vinkovaca do Prevlake, uključujući i bodule [tzn. wzdłuż i wszerz terytorium Chorwacji — przyp. M.S.], ali nam prevoditelj to prevede kao „svi su kurili na rat”, što mogu razumjeti, eventualno, žitelji Zagrebačke županje, iako ni sami takvu frazu ne koriste (Jergović 1999).

Czasownik ložiti jest stosowany zarówno w języku chorwackim, jak i serbskim. Hrvatski jezični portal (HJP) podaje także synonim kuriti, ale używany on jest w dialekcie kajkawskim występującym w Zagrzebiu oraz Słowenii (podstawa dla języka literackiego), dlatego dla pozostałych Chorwatów — przynajmniej teoretycznie może być niezrozumiały. Jednakże praca tłumacza przy filmie Rane w największym stopniu dotyczyła zmiany z ekawicy na ijekawicę oraz kilku słów uznanych za zbyt serbskie na „czysto” chorwackie.

Chorwackie prawo medialne w artykule 4 ustęp 1 nakazuje tłumaczenie z języków obcych na język chorwacki (Zakon o elektroničkim medijima). Jak w tej interpretacji prawnej wygląda język serbski? W ocenie lingwistów i znawców mediów przekład nie jest nielegalny, ale uznają jego zastosowanie za zbędne. Odpowiedzialności prawnej podlegałby brak przełożenia np. z języka angielskiego na chorwacki, ale w przypadku języka serbskiego w toku potencjalnego „śledztwa” okazałoby się, że są to bliskie sobie języki. Innego zdania jest regionalna organizacja pozarządowa zajmująca się środkami masowego przekazu — South East Europe Media Organisation (SEEMO) ${ }^{8}$. W styczniu 2012 roku uznała za zasadne tłumaczenie z języka serbskiego na chorwacki i na odwrót. Zdaniem SEEMO jest to analogiczna sytuacja np. do przekładu filmów niemieckich w Austrii oraz austriackich w Niemczech. W pewnym momencie również i w Serbii popularyzowano ideę thumaczenia filmów chorwackich, ale ostatecznie z niej zrezygnowano. Jak argumentował dyrektor Instytutu Języka Serbskiego (Institut za srpski jezik), Sreto Tanasić, nie istnieje potrzeba thumaczenia z serbskiego na chorwacki (Ristić 2012).

Kontrowersje związane $\mathrm{z}$ tłumaczeniem z języka serbskiego wciąż są aktualne. $\mathrm{Na}$ przykład telewizja chorwacka RTL w 2012 roku nie dopuściła do emisji serialu serbskiego Žikinja dinastija, ponieważ nie został przetłumaczony z języka „obcego”, tj. serbskiego, na chorwacki. Są to jednak sytuacje wyjątkowe, sporadyczne, większość produkcji serbskich (też bośniackich i czarnogórskich) jest bowiem regularnie emitowana w telewizji chorwackiej bez napisów (choć pojawiają się inicjatywy umożliwienia widzom chorwackim opcjonalnej możliwości wsparcia się przekładem). Jeden z najnowszych przykładów thumaczenia z języka serbskiego z użyciem napisów chorwackich to program 24Kitchen

\footnotetext{
${ }^{8}$ Organizację założono pod koniec 2000 roku w Zagrzebiu. Zajmuje się szeroko pojętą poprawnością przekazu medialnego w Europie Południowo-Wschodniej.
} 
$T V$ (2014 rok). Jednym z gości był kucharz serbski Nenad Veljković. Wyglądało to w następujący sposób (kilka wyrywkowych przykładów):

\begin{tabular}{|c|c|}
\hline kucharz serbski & napisy chorwackie \\
\hline Malo ćemo da promešamo, evo ovako. & Malo ćemo promiješati, evo ovako. \\
\hline $\begin{array}{l}\text { Da probamo i vidimo kakvog je ukusa. } \\
\text { (pirinač - rodzaj męski) }\end{array}$ & $\begin{array}{l}\text { Da kušamo i i vidmo kakva je okusa. (riža- } \\
\text { rodzaj żeński) }\end{array}$ \\
\hline $\begin{array}{l}\text { Malo soli. Nemojte preterivati. Jednostavno, } \\
\text { nema potrebe jer sve ovo povrće ima svoju } \\
\text { slatkoću. }\end{array}$ & $\begin{array}{l}\text { Malo soli. Nemojte pretjerivati. Nema potrebe } \\
\text { jer sve ovo povrće ima svoju slatkoću. }\end{array}$ \\
\hline $\begin{array}{l}\text { Malo senfa, belog luka, pavlake i ko } \\
\text { bombona. }\end{array}$ & Malo senfa, češnjaka, vrhnja i odlično. \\
\hline 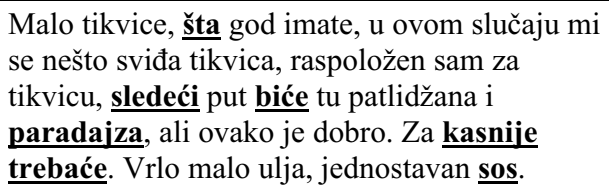 & $\begin{array}{l}\text { Malo tikvice, što god imate, u ovom mi se } \\
\text { slučaju baš sviđa tikvica, raspoložen sam za } \\
\text { tikvice, sljedeći put bit će tu patlidžana i } \\
\text { rajčice, ali ovako je dobro. Trebat će za } \\
\text { poslije. Vrlo malo ulja, jednostavan umak. }\end{array}$ \\
\hline
\end{tabular}

Powyższe przykłady wskazują, że różnice występują na kilku poziomach. Po pierwsze, w fonetyce: ekawica-ijekawica (promešamo-promiješati, preterivati-pretjerivati, sledeći-sljedeći), czy ukus-okus (u-o). Jak wskazuje Hrvatski jezični portal, okus to smak, a ukus gust, a w języku serbskim ukus to zarówno smak, jak i gust. Po drugie, w leksyce. W przypadku probamo-kušamo (probati-kušati) oba czasowniki są zamiennie stosowane zarówno w języku chorwackim, jak i serbskim. Czasownik kušamo został użyty wyłącznie po to, aby stworzyć pozory odmienności językowej. Inne rozbieżności leksykalne to: beli luk-češnjak, pavlaka-vrhnje, paradajz-rajčica. W tym przypadku tłumaczenie może być potrzebne, ponieważ beli luk, uhar oraz paradajz są rzeczownikami charakterystycznymi dla języka serbskiego, a češnjak, vrhnje, rajčica dla chorwackiego, choć czasami m.in. paradajz używany jest przez Chorwatów (Hrvatski jezični portal uznaje go za regionalizm). Kolejna różnica to rzeczownik sos-umak. Pierwsza forma jest stosowana również w języku chorwackim, ale mimo to ponownie użyto ekwiwalentu, aby udowodnić odmienność języków.

W przypadku języka serbskiego została zastosowana także forma da + praesens (składnia). Zamiast formy bezokolicznikowej Malo ćemo promešati użyto Malo ćemo da promešamo, czyli czasownika w odpowiedniej formie osobowej (w tym przypadku pierwsza osoba liczby mnogiej). Jednakże w języku serbskim również może być użyty bezokolicznik jak w tym przypadku: Nemojte preterivati (w miejsce Nemojte da preterivate). Forma $\mathrm{z}$ da nie występuje w języku chorwackim, choć nie zakłóca to rozumienia przekazu. Różnice występują także w zapisie czasu przeszłego biće-bit će oraz trebat će-trebaće (wspomniana wyżej kontaminacja; ortografia) oraz w użyciu što-šta. Zaimek što i šta używany jest w języku serbskim, w zależności od kontekstu. Što stosuje się w sytuacjach przyczynowo-skutkowych, np. Izvini što kasnim, a nie Izvini šta 
kasnim. Wówczas što oznacza ,że, ponieważ”, choć czasami stosowane jest što jako „co”. W pozostałych kontekstach używane jest šta oznaczające „co”, a w języku chorwackim formalnie što, choć šta nie jest formą obcą w języku potocznym.

Trzeba podkreślić jeszcze inną ważną kwestię. Chorwacko-serbski kontrast językowy, tak pożądany przez Chorwatów, został dokonany za pomocą wyrażeń bliskoznacznych, a nie odmiennych ekwiwalentów. Na przykład określenie ko bombona dosłownie oznacza jak cukierek, co jest metaforycznie można oddać jako wspaniale, cudownie. Metafora ta może być z powodzeniem używana również w języku chorwackim, ale w przekładzie tłumacz uznał, że bardziej chorwacka jest forma odlično, stosowana regularnie i w serbskim. Ten sam zabieg powtórzono również w określeniu za poslije-za kasnije. Obie formy używa się bowiem wymiennie, i w serbskim (za posle), i w chorwackim, oznaczając to samo (później).

$$
* * *
$$

Na rynku translatorskim byłej Jugosławii funkcjonuje wiele firm trudniących się tłumaczeniem m.in. z języka chorwackiego na serbski, bośniacki oraz chorwacki - na przykład firma chorwacka „abc prijevodi”. Z kolei firmy serbskie w większości oferują wyłącznie przekład na chorwacki, ponieważ odmienność bośniackiego ${ }^{9}$ oraz czarnogórskiego mocno kwestionują. Przykładowo firma serbska „Worldwide Translations” praktykuje nawet przekład z chorwackiego na serbski, nie tylko z serbskiego na chorwacki, zaznaczając tym samym: „Govornici hrvatskog i srpskog jezika odlično se razumeju. Nekada je zajedno sa srpskim činio jedinstven srpskohrvatski jezički standard" (Worldwide Translations). Po stronie chorwackiej wzmianki o wspólnocie językowej są rzadkością, a oferty translatorskie na język bośniacki i czarnogórski mogą potwierdzać stanowisko chorwackie, że są to języki różniące się, tak jak chorwacki.

Czy przekłady na bliskie sobie języki są rzeczywiście potrzebne? Z jednej strony ze względu na wspólną genezę nie, ale z drugiej zaś, w związku z różnicami terytorialnymi (nie narodowymi; m.in. beli luk-češnjak), czasami występuje potrzeba takiego zabiegu, choć można odnieść wrażenie, że podyktowana jest ona pobudkami politycznymi (np. wspomniane probamo-kušamo). Warto zaznaczyć, że potrzeba wsparcia się przekładem potencjalnie może dotyczyć nowej generacji, która uczy się „oczyszczonego" języka (przypadek Chorwacji i powoli Czarnogóry). Dla starszych pokoleń chorwackich na przykład pasoš będzie leksemem zrozumiałym, niejako naturalnym, dla młodszej może być jednak czasami niejasny, gdyż będą znali wyłącznie rzeczownik $p u$ tovnica. Nie jest to jednak reguła, można spotkać bowiem młodsze pokolenia Chorwatów używające rzeczownika pasoš, co tym bardziej pokazuje, że polityka pu-

\footnotetext{
${ }^{9}$ Pozostawiając kwestie negowania istnienia języka bośniackiego, warto zaznaczyć, że część lingwistów serbskich optuje za nazwą bošnjački jezik, a nie bosanski. Argumentują to faktem, że leksem bosanski, nacechowany terytorialnie, a nie narodowo, zostaje przywłaszczony przez Bośniaków, eliminując Chorwatów i Serbów z prawa przynależności do państwa bośniackiego. Uznają zatem, że adekwatniejsza nazwa to język bośniacki, nawiązujący do narodu bośniackiego. Czasami nawet sami muzułmańscy mieszkańcy Bośni i Hercegowiny optują za nazwą bošnjački.
} 
ryzmu nie zawsze odnajduje odzwierciedlenie wśród rodzimych użytkowników języka chorwackiego.

W przypadku języka serbskiego potrzeba tłumaczenia, a raczej objaśnienia, jest wskazana na przykład ze względu na charakterystyczny dla tego języka sposób zapisu nazw obcych. Vuk Karadžić wprowadził zasadę ,piši kao što govoriš, čitaj kao što je napisano", co oznacza, że obce słowa zapisywane są w sposób fonetyczny. Na przykład godność byłego pierwszego niekomunistycznego prezydenta III Rzeczpospolitej zostanie zapisana w następujący sposób: Leh Valensa, a w przypadku języka bośniackiego i chorwackiego w sposób oryginalny, tzn. Lech Wałęsa ${ }^{10}$. Zarysowane powyżej najczęściej występujące różnice pomiędzy chorwackim a serbskim: ijekawica-ekawica, np. inne formy zapisu czasu przyszłego czy leksykalne, nie stanowią jednak znaczącej bariery we wzajemnym rozumieniu.

Język czarnogórski wciąż jest traktowany (zwłaszcza przez Serbów) jako regionalny wariant serbskiego w wersji ijekawskiej. W 2009 roku wydano oficjalny, autoryzowany przez władze czarnogórskie, Pravopis crnogorskoga jezika i Rječnik crnogorskoga jezika, wprowadzony wkrótce do szkół, a także uniwersytetów ${ }^{11}$. Część lingwistów czarnogórskich (głównie Adnan Čirgić) standard języka czarnogórskiego oparła na dialekcie starosztokawskim (wariant zecki), co według nich stanowi pierwotną i właściwą podstawę dla języka czarnogórskiego. Należy jednak mieć na uwadze, że w Czarnogórze występował również dialekt wschodniohercegowiński, który wraz z przyjęciem reformy vukowskiej zyskał prestiż. Odejście od tego stanu jest krytykowane nie tylko przez Serbów, ale też i samych Czarnogórców, którzy uznają to za niepotrzebną archaizację języka czarnogórskiego. Według nich promowane stare wyrazy, jak np.: pamidor, pirun, pjat oraz tavulin, nie są używane, a nawet — co najważniejsze — znane. Czarnogórcy wciąż używają leksemów: paradajz, viljuška, tanjir i sto, czyli tych charakterystycznych dla języka serbskiego oraz podstawy nowosztokawskiej (Komatina 2012: 169). Przypomina to chorwacką politykę językową, tj. dążenie do zanegowania istniejącej przez tyle lat bliskości językowej.

Język bośniacki początkowo miał pełnić rolę integracyjną, ponadnarodową, ale w związku z podziałem na język chorwacki i serbski został przypisany Boszniakom. Ich język wyróżnia m.in. fonem h (w niektórych pozycjach, np. kahva, w odróżnieniu od leksemu serbskiego - kafa oraz chorwackiego - kava) czy liczne orientalizmy, głównie turcyzmy (Isaković 1997: 69). Należy jednak zaznaczyć, że żadna instytucja nie kodyfikuje tych zasad, dlatego przebiega ona w sposób nieformalny, wyłącznie m.in. na podstawie różnych słowników. Innymi słowy, bośniacka praktyka językowa pozostaje

${ }^{10}$ Inne przykłady: godność amerykańskiej piosenki Beyonce Knowles po serbsku zostanie zapisana Bijonse Nouls, amerykańska aktorka Angelina Jolie - Andželina Džoli, czasem Žoli itd.

11 W 2008 roku w Nikšiciu otwarto pierwszą katedrę języka czarnogórskiego, a w 2014 roku drugą w Cetinju. W związku z tym doszło do otwartego konfliktu pomiędzy językoznawcami czarnogórskimi o zasady kodyfikacji języka czarnogórskiego, choć antagonizmy te zarysowały się już podczas normowania czarnogórskiego standardu (2008-2009). Uznaje się zatem, że jest to tzw. „tląca się wojna” (tinja rat), gdyż wykładane są dwie różne formy jednego języka. 
wciąż nieujednolicona (choć kodyfikacja nie zawsze wpływa na użycie promowanego standardu), dlatego język Boszniaków wciąż jest in statu nascendi. Ponadto bosanski jezik oscyluje pomiędzy językiem chorwackim i serbskim, dlatego — jak zauważa Maciej Czerwiński - jego norma jest ,niestabilna, płynna, potencjalna oraz nieprzewidywalna" (Czerwiński 2006: 69). W związku z tym tłumacz ma przed sobą ogromne wyzwanie, ponieważ nie wiadomo dokładnie, który termin będzie właściwszy dla języka bośniackiego. Dla przykładu, Boszniacy mieszkający przy granicy z Chorwacją oraz ci, którzy po prostu obracają się wśród sąsiadów chorwackojęzycznych, zupę nazwą juha, a ci znajdujący się blisko wpływów serbskich — supa. Inny przykład to ciśnienie, które na bośniacki przetłumaczymy - również i na serbski - jako pritisak. Jednakże urządzenie pod ciśnieniem w języku bośniackim nie będzie takie samo jak w serbskim - oprema pod pritiskom, tylko tlačna oprema, co jest charakterystyczne dla języka chorwackiego (ciśnienie to tlak). Zdarzają się też sytuacje, że jeden tekst zawiera raz leksem charakterystyczny dla chorwackiego, a w następnym akapicie już ten właściwy dla serbskiego. Takich przykładów można pokazać jeszcze wiele, choć ciężko jednoznacznie stwierdzić, czy leksyka języka bośniackiego opiera się bardziej kroatyzacji czy serbizacji, ale nie wlicza się do niej jeszcze języka potocznego Boszniaków.

\section{ETYKIETY NA PRODUKTACH}

W przypadku oznakowań na produktach (w artykule tym zostaną przytoczone tylko przykłady produktów spożywczych) sytuacja wygląda podobnie. Nie są to jednak skróty języków (ISO 639), ale państw ${ }^{12}$, tj. ISO 3166-1 alfa-3: BIH (Bośnia i Hercegowina), MNE (Czarnogóra; czasem, choć nieoficjalnie jako CG), SRB (Serbia; nieformalnie niekiedy RS) oraz ISO 3166-1 alfa-2: HR (Chorwacja; forma alfa-3 HRV nie jest spotykana), których kodyfikacją zajmuje się Międzynarodowa Organizacja Normalizacyjna (International Organization for Standardization, ISO). W związku z tym, że podział nastąpił według państw, a nie języków, na oznaczeniach etykiet można zauważyć tendencję przywłaszczania sobie języka danego państwa lub próby „tłumaczenia”, czyli zamiany własnej leksyki na tą charakterystyczną dla innego obszaru. Jednakże zabiegi te przebiegają w sposób nieregularny, dlatego trudno wskazać na jedną dominującą regułę, można wyłącznie odnotować kilka ciekawych obserwacji.

Kiedy producentem jest Republika Serbii, można dostrzec dwie tendencje. Do pierwszej grupy towarów zaliczymy te, które posiadają łączne oznaczenie SRB/MNE/BIH (np. krem orzechowo-czekoladowy „Eurocrem” lub majonez „Polimark”), ponieważ są one wwożone do Bośni i Hercegowiny oraz Czarnogóry, a także sprzedawane na terytorium serbskim. Opis właściwości danego artykułu zapisany jest ekawicą, choć dla Bośni i Czarnogóry właściwa jest ijekawica. Oznacza to także, że cały obszar językowy czarnogórski oraz bośniacki utożsamiany jest z językiem serbskim. W latach 90 . XX wieku na tych terenach — nieskutecznie — próbowano przypisać ekawicy i cyrylicy

\footnotetext{
${ }^{12}$ Również jednostek administracyjnych.
} 
dominującą rolę (Jaroszewicz 2004: 227, 232-233, 235) ${ }^{13}$. Serbowie rozpoczęli wówczas proces „reserbizowania” (resrbljivanje) swojego języka, który w przeciwieństwie do sąsiedniej Chorwacji nie polegał na czyszczeniu języka, ale na umocnieniu jego cech odróżniających, czyli wspomnianej ekawicy i cyrylicy. Łacinka np. została uznana za tuđinsko i hrvatsko pismo (Bugarski 2013: 102). Godnym uwagi jest fakt, że mimo walki o prymarny charakter cyrylicy (kontynuowanej i dziś) ${ }^{14}$ oraz prób wchłonięcia bośniackiego i czarnogórskiego obszaru językowego w obręb serbskiego na etykietach nie używa się cyrylicy, tylko łacinkę. Można zatem uznać, że w komercyjnej praktyce językowej ów postulat nie został przyjęty. Bliskość językowa oraz łacinka pozwala więc na dotarcie produktu do szerszego kręgu klienteli (np. do Chorwatów), aczkolwiek z zachowaniem cech uznanych za serbskie. Czasami jednak produkty wytwarzane w Serbii i dystrybuowane w Czarnogórze nie posiadają żadnych oznakowań, a zapisane są ekawicą (np. herbatniki „Keksići čajno pecivo”).

Inna grupa produktów serbskich posiada już rozgraniczenia, np. zupa instant „Domaća - Kokošija bistra supa”:

\begin{tabular}{|c|c|}
\hline $\mathrm{SRB} / \mathrm{MNE}$ & 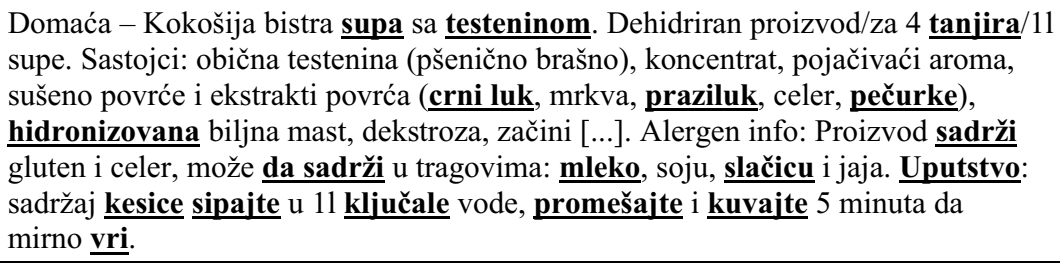 \\
\hline BIH/HR & 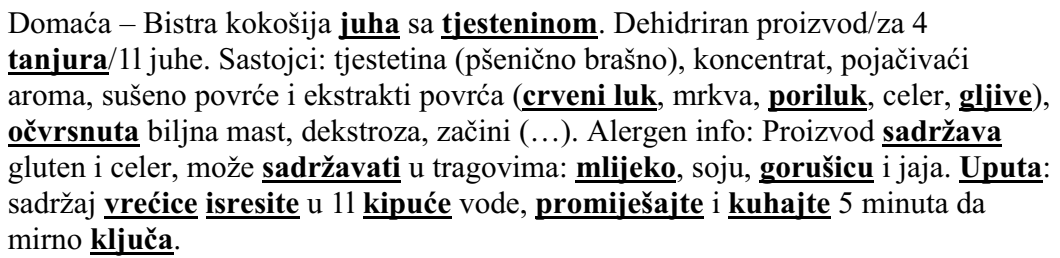 \\
\hline
\end{tabular}

Czarnogórski obszar językowy ponownie został „wchłonięty” w serbski (ekawica), a bośniacki zrównany z chorwackim, głównie przez występowanie w Bośni ijekawicy. Jednak jak wykazano wcześniej leksyka języka bośniackiego jest „mieszanką” chorwacką i serbską. Ponadto językiem urzędowym w Bośni jest także język serbski w wymowie ijekawskiej, ale w istocie nie odbiega on od standardu w Serbii (choć można odnaleźć pew-

${ }^{13}$ Fiasko projektu ekawizacji spowodowane było przede wszystkim faktem, że ekawica na terenach bośniackich i czarnogórskich nigdy nie miała tradycji (tak samo jak ijekawica w Serbii, stąd ostatecznie nie przyjęto reformy Karadžicia). W 1998 roku Trybunał Konstytucyjny Republiki Serbskiej uznał przyjętą w 1996 roku ustawę o nakazie ekawizacji za niezgodną z ustawą zasadniczą. W tym samym roku w Czarnogórze prezydentem został Milo Đukanović, który zmienił orientację polityczną z proserbskiej na proczarnogórską, dlatego ekawizację uznał za hegemonizm serbski.

${ }^{14}$ W Konstytucji Republiki Serbii z 2006 roku za jedyne oficjalne pismo uznaje się właśnie cyrylicę. We wcześniejszych aktach normatywnych łacinka pełniła funkcję pomocniczą. Dziś jednak pozostaje nieoficjalnym, aczkolwiek często stosowanym alfabetem przez Serbów, w czym widzi się zagrożenie dla tradycyjnego pisma serbskiego. 
ne regionalne różnice np. w akcencie). Tak jak w przypadku tłumaczenia programu 24Kitchen $T V$ różnice pomiędzy tymi dwoma oznaczeniami przebiegają na tych samych płaszczyznach. Po pierwsze, fonetyka: ekawica-ijekawica (testenina-tjestenina, promešajte-promiješatje, mleko-mlijeko) oraz tanjir-tanjur (i-u), kuvati-kuhati (v-h). Po drugie, leksyka: supa-juha, praziluk-poriluk, pečurke-gljive, slačica-gorušica. Należy zaznaczyć, że pečurka występuje też w języku chorwackim, a gljiva w serbskim. Tę wymianę zaobserwować można również w przypadku slačica i gorušica, co pokazuje, że wszystkie te leksemy są synonimami. W zamiennikach leksykalnych można odnaleźć też pewien ,błąd”. Otóż crni luk (biała cebula) w oznaczeniu HR/BIH został ,przetłumaczony" jako crveni luk tj. czerwona cebula, co już jest innym rodzajem skądinąd tego samego warzywa. Określenia očvrsnut-hidronizovan oznacza oczyszczony z wody, ale należy zaznaczyć, że forma bierna očvrsnut (od czasownika očvrsnuti) jest właściwa zarówno dla języka chorwackiego, jak i serbskiego. Została ona jednak użyta, aby odróżnić się od strony serbskiej, a można było użyć odpowiednika chorwackiego - hidroniziran. Wówczas byłaby to różnica na poziomie słowotwórstwa — dwa różne sufiksy czasownikowe -ovati i -irati. Różnicą słowotwórczą jest też uputsvo-uputa (-stvo i -a).

Ciekawy przypadek to ključala voda-kipuća voda oraz da mirno vri-da mirno ključa. Czasownik ključati występuje zarówno w języku chorwackim, jak i serbskim. Jednak w przekładzie na BIH/HR został zastosowany przymiotnik kipuća, tak aby się odróżnić, choć forma ta również stosowana jest w języku serbskim. Fakt, że czasownik ključati używany jest w języku chorwackim, udowadnia przykład da mirno ključa. W przekładzie serbskim został wykorzystany czasownik vreti (da mirno vri), który używany jest w języku chorwackim. Przykład ten pokazuje, że różnice podkreśla się wyłącznie synonimami. Tak samo rzecz ma się w przypadku kesice-vrećice. Oba rzeczowniki są stosowane w dwóch językach wymiennie, ponieważ ich znaczenie jest podobne (siateczka-woreczek). W przypadku kesica (zdrobnienie od kesa) Hrvatski jezični portal zaznacza, że jest to występujący w określonych regionach serbizm (nie dziwi zatem, dlaczego został zastąpiony. Tak samo jak w przypadku supa, co zostało uznane za regionalizm pochodzenia serbskiego). Również użycie: može da sadrži-sadržava, tzn. odpowiednio formy dokonanej czasownika (wraz z konstrukcją z da) i niedokonanej, jest niepotrzebne, ponieważ znaczenie jest to samo (może zawierać a zawiera). W języku serbskim mógłby być zastosowany czasownik niedokonany sadržavati, nawet bez konstrukcji z da.

Ogólnie rzecz biorąc Serbowie nie uznają odrębności języka czarnogórskiego (do 2007 roku językiem urzędowym w Czarnogórze był język serbski w wymowie ijekawskiej, później zastąpiony przez czarnogórski), dlatego za każdym razem utożsamiają go z kodem serbskim. W przypadku języka bośniackiego i chorwackiego czasami praktykuje się „tłumaczenie”, ale wówczas te dwa języki serbscy producenci wrzucają do przysłowiowego jednego worka. Przede wszystkim jest to czysto marketingowe posunięcie, dostosowanie się do klienteli. Ścierają się tutaj dwie płaszczyzny: pragmatyczna (uznajemy odrębność językową, by sprzedać) oraz ta podgrzewana z pobudek politycznych, nacjonalistycznych, czyli nieuznawanie języka bośniackiego, czarnogórskiego, a także chorwackiego i traktowanie ich jako dialektów języka serbskiego (oznaczenie 
$\mathrm{SRB} / \mathrm{MNE} / \mathrm{BIH})$. Warto jeszcze zwrócić uwagę na interesującą rzecz. Zabiegi komercyjne stoją bowiem w wyraźnej sprzeczności w stosunku do firm serbskich trudniących się tłumaczeniem, które oferują wyłącznie przekład na język chorwacki. Również i tutaj — oczywiście z chęci zysku — można byłoby rozszerzyć ofertę translatorską.

Artykuły spożywcze wytwarzane w Bośni i Hercegowinie, jeśli są przeznaczone na sprzedaż w obrębie tego państwa, posiadają napisy w trzech językach urzędowych: bośniackim, chorwackim oraz serbskim (artykuł 6 Konstytucji Federacji Bośni i Hercegowiny; inny zapis widnieje w ustawie zasadniczej Republiki Serbskiej: „Službeni jezici Republike Srpske su: jezik srpkog naroda, jezik bošnjačkog naroda i jezik hrvatskoga naroda"; Katnić-Bakaršić 2013: 120). Bodaj najpopularniejsze są trzy identyczne napisy na paczkach papierosów. Jedna z wersji wygląda następująco: Pušenje ubija, Pušenje ubija oraz Пушење убија. Na różnych forach można odnaleźć prześmiewcze komentarze typu: „Mene samo zanima koji je hrvatski a koji bosanski jezik?”. Ta formuła wygląda tak samo dla trzech języków, ale w przypadku języka serbskiego uznano cyrylicę za właściwy alfabet, co ma podkreślić „odrębność”.

Inny produkt wytwarzany w Bośni i Hercegowinie (np. ciastka - Zlatni Lokum. Čajno pecivo sa orahom i puterom), dystrybuowany w Chorwacji, Czarnogórze oraz Serbii, zawiera trzy oznaczenia: BIH/HR, SRB oraz MNE.

\begin{tabular}{|c|c|}
\hline $\mathrm{BIH} / \mathrm{HR}$ & 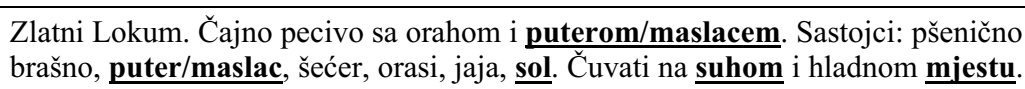 \\
\hline SRB & $\begin{array}{l}\text { Zlatni Lokum. Čajno pecivo sa orahom i puterom. Sastojci: pšenično brašno, } \\
\text { puter, šećer, orasi, jaja, so. Čuvati na suvom i hladnom } \underline{\text { mestu. }}\end{array}$ \\
\hline MNE & $\begin{array}{l}\text { Zlatni Lokum. Čajno pecivo sa orahom i puterom. Sastojci: pšenično brašno, } \\
\text { puter, šećer, orasi, jaja, so. Čuvati na suvom i hladnom } \underline{\text { mjestu. }}\end{array}$ \\
\hline
\end{tabular}

Oznaczenie SRB i MNE różni się tylko jednym szczegółem fonologicznym: mesto-mjesto. Ciekawa jest formuła zastosowana w BIH/HR, tj.puter/maslac. Po pierwsze, uwzględniono tutaj leksykę charakterystyczną dla języka chorwackiego (maslac), a także dla serbskiego (puter). Po drugie, umieszczenie ich razem odnosi się do wariantywności bośniackiego obszaru językowego, choć już w przypadku różnicy fonologicznej suh-suv tego nie zastosowano $(h-v)$. Powyższy przykład pokazuje, że akurat w przypadku tego konkretnego produktu rozdzielenie nie jest potrzebne, można byłoby napisać jedno oznaczenie BIH/HR/SRB/MNE, uwzględniając oczywiście cztery „różnice”: puter/maslac, suhom/suvom, so/sol oraz mjestu/mestu. Interesujące jest także, że MNE zostało oddzielone od SRB, a BIH od HR już nie.

Nawiązując do leksemów puter-maslac na przykładzie ciastek wypiekanych w Serbii (Wellnes - integralni keks sa crnom čokoladom i pomarandžom) można zauważyć, że również maslac został uznany za właściwy dla języka serbskiego (SRB/MNE). Pokazuje to, że w tych czterech językach występują wymienne ekwiwalenty leksykalne, dlatego trudno czasami znaleźć ostre rozgraniczenie (na tej podstawie można przypuszczać, że języki te nie są zróżnicowane narodowo, a regionalnie). Nad tym problemem zastanawiał się też pisarz serbski Teofil Pančić, w kontekście tłuma- 
czenia filmu Rane. Rozważał on bowiem „serbski charakter” hleba i „chorwacki charakter" kruha, przytaczając przykład Serbów mieszkających w Chorwacji i Chorwatów w Serbii (Pančić 1999). Należy zaznaczyć, że wskazana wariantywność częściej odnosi się jednak do bośniackiego obszaru językowego, choć jak widać można się z nią spotkać także w Serbii.

W oznaczeniach na produktach z Bośni i Hercegowiny (też z Serbii) najczęściej jednak bośniacki obszar językowy zostaje wpisany do chorwackiego (np. napój gazowany Coca-Cola produkowany w Sarajewie i dystrybuowany w Chorwacji nie zawiera żadnych oznaczeń), choć zdarzają się też występować rozdzielnie (np. na opakowaniu cukru $A G R A G O L D)$ :

\begin{tabular}{|l|l|}
\hline BIH & $\begin{array}{l}\text { AGRAGOLD bijeli kristalni šećer. Datum pakovanja/Lot: otisnut na ambalaži. } \\
\text { Čuvati na suhom mjestu. Zemlja porijekla: Proizvedeno u Bosni i Hercegovini. }\end{array}$ \\
\hline HR & $\begin{array}{l}\text { AGRAGOLD bijeli kristalni šećer. Datum pakiranja/Lot: otisnut na ambalaži. } \\
\text { Čuvati na suhom mjestu. Zemlja podrijetla: Proizvedeno u Bosni i Hercegovini. }\end{array}$ \\
\hline
\end{tabular}

Zaznaczone są tutaj dwie różnice. Po pierwsze, słowotwórstwo, tj. różne sufiksy rzeczownikowe -ovanje i -iranje. Pakovanje jest właściwe dla języka serbskiego, więc w tym przypadku językowy obszar Bośni utożsamiony został nie z chorwacką (pakiranje), a serbską leksyką. Kilka słów dalej zauważamy, że obszar językowy Chorwacji i Bośni może być jednak zrównany (suhom, dla języka bośniackiego odpowiednie może być też suvom). Wskazane oznaczenie można byłoby zapisać jako jedno, ale z uwzględnieniem wariantywności pakovanja/pakiranja. Z kolei obie formy porijeklo i podrijetlo uznaje się za typowe dla języka chorwackiego. Hrvatski jezični portal wskazuje, że porijeklo jest częstsze, a podrijetlo to rzadszy synonim. Paradoksalnie jednak podrijetlo ma bogatszą tradycję w języku chorwackim, a ponadto można je uznać za serbizm (zgodnie z analizą Ivo Pranjkovicia, zob. więcej: Czerwiński 2005: 230), stąd jednak przewaga porijeklo. Nie jest to jednak reguła, co pokazuje powyższy przykład, a podrijetlo zostało użyte, aby odróżnić bośniacki obszar językowy od chorwackiego.

Inne artykuły produkowane w Bośni i Hercegowinie zawierają oznaczenia czterech państw, tj. HR, SRB, MNE oraz BIH (np. Tuzilanska sol). Identyfikatory SRB i MNE nie różnią się od siebie, ale w porównaniu do HR oraz BIH zawierają inny przymiotnik określający sól - evaporisana so (odparowana, oczyszczona z wody sól). W przypadku odnośnika HR użyto — kamena sol (kamienna sól), a BIH — varena so (forma bierna od czasownika variti - gotować, czyli gotowana sól ${ }^{15}$ ). Występuje tu chaos, poprzez sztuczne zaznaczenie odmienności. Warto jednak zaznaczyć, że producent bośniacki przeważnie rozgranicza języki - na trzy urzędowe w Bośni i Hercegowinie (wspomniane napisy na paczkach papierosów) lub na języki urzędowe innych państw - SRB, MNE, czasem HR lub HR/BIH. Takie zabiegi mają udowodnić, że wszystkie języki są równouprawnione, ale uwypukla się przy tym wątpliwe różnice, o czym świadczy przykład produktu Tuzilanska sol. Na marginesie można zaznaczyć, że w instrukcjach

${ }^{15}$ Polskim odpowiednikiem jest sól warzona. 
konsumenckich podane zostały inne wartości jodu w soli: $\mathrm{HR}-15 / 23 \mathrm{mg} / \mathrm{kg}$, SRB i MNE $-12 / 18 \mathrm{mg} / \mathrm{kg}$, a dla BIH $-20 / 30 \mathrm{mg} / \mathrm{kg}$. Ta absurdalna sytuacja była często komentowana na różnych portalach bośniackich. Zastanawiano się bowiem, czy ten sam produkt zawiera odmienne właściwości (gorsze lub lepsze), w zależności jakim językiem się posługujemy, tzn. jeśli mówimy bośniackim językiem, to produkt ten automatycznie zawiera wyższe parametry?

W przypadku produktów chorwackich i czarnogórskich, jeśli są produkowane dla rodzimego konsumenta, nie zawierają żadnych oznaczeń, w odróżnieniu od produktów serbskich (choć czasami i tutaj ich nie ma; wspomniany przykład herbatników) i bośniackich (jednak tutaj pojawiają się napisy w trzech językach urzędowych Bośni). W przypadku Chorwacji mogłoby się wydawać, że również ona będzie rozgraniczać języki, tak jak Bośnia i Hercegowina, aby podkreślić zasadność takiego kroku i potwierdzić, że są to jednak inne języki. Jednakże, jak wspomniano na początku, oznaczenia na produktach wykazują się pewną nieregularnością i tego przykładem jest właśnie producent chorwacki. Nie rozdziela on języków, np. czarnogórskiego (czekoladki dla dzieci Lino Čokolino), w którym używa ekawicy, a nawet konstrukcję z da, czyli wpisuje kod czarnogórski do serbskiego. W przypadku innego produktu można zauważyć pewien błąd (mleko la FATTORIA, sprowadzane z zagranicy, ale dystrybuowane przez Chorwację w całym regionie bałkańskim, też w Macedonii, Albanii i Kosowie). Oddzielne oznaczenie MNE zawiera bowiem czasownik kuhati (język chorwacki), a nie kuvati (język serbski; odmienność fonologiczna h-v). Można przypuszczać zatem, że użycie czasownika charakterystycznego dla chorwackiego jest przeoczeniem, a nie celowym zabiegiem, gdyż w całym thumaczeniu użyta jest leksyka identyczna jak w przypadku SRB (oprócz różnic fonologicznych ekawica-ijekawica). Producent chorwacki eksportując dany produkt umieszcza na nim jednak oznaczenie HR/BIH lub SRB/MNE, czasem też oddzielając je. Jest to tożsame z zabiegiem, który dokonuje wytwórca serbski. Warto zaznaczyć, że z jednej strony firmy translatorskie oferują oddzielne thumaczenia na języki bośniacki i czarnogórski, ale czasami chorwacki przedsiębiorca odmienności nie uwzględnia.

\section{PODSUMOWANIE}

Powyższe przykłady nie wyczerpują tematu, z pewnością można odnaleźć wiele innych, które pokazałyby zwiększoną konieczność skorzystania z pomocy translatorskiej. Jednakże drobiazgowe rozróżnianie języków chorwackiego i serbskiego (nie bośniackiego i czarnogórskiego, które są marginalizowane, dlatego wchłaniane są do chorwackiego lub serbskiego kodu) nie jest zabiegiem niezbędnym, głównie przede wszystkim na fakt, że wywodzą się one z nowosztokawskiego pnia. Siłą rzeczy różnice systemowe nie są na tyle znaczące, co otwiera realną możliwość wzajemnej komunikacji oraz zrozumienia.

Prawdopodobnie rozgraniczenia SRB, MNE, HR czy BIH są dostosowane do konsumenta, ponieważ może on przywiązywać wagę do odrębności językowych. Dla in- 
nego klienta, dla którego nie jest to istotne, eksponowanie różnić wywoła tylko ironiczny uśmiech. Może nawet nie zwrócić uwagi na łączne oznaczenie SRB/MNE/BIH. Inna grupa produktów nie posiada odrębnych instrukcji konsumenckich, co teoretycznie może oznaczać, że producent nie widzi potrzeby rozgraniczenia, nie uznając rozbieżności, i nie musi to być podyktowane nacjonalistycznymi względami (choć czasami na pewno jest). W przypadku etykiet powstaje niepotrzebny chaos, a wskazane przykłady z całą pewnością pokazują, że taki nieporządek nie jest konieczny, ponieważ użytkownicy tych czterech języków znakomicie się rozumieją. W ocenie autorki niezbędne jest tutaj odpowiednie unormowanie prawne, które hipotetycznie mogłoby częściowo uporządkować zasady zapisu na etykietach.

Powyższe przykłady unaoczniają też, że największe odrębności występują głównie na płaszczyźnie leksykalnej, co czasami uzasadnia wsparcie się „,przekładem”. Jednak nie w momencie, gdy różnią się one m.in. jedną ekwiwalentną głoską fonologiczną (np. kuhati-kuvati; $h-v)$. Przytoczone przykłady udowadniają także, że szukanie czy wręcz wynajdywanie różnic (np. przede wszystkim poprzez zastosowanie wyrazów bliskoznacznych) jest zabiegiem wymuszonym, celowym, podgrzewanym przede wszystkim przez nacjonalistyczne względy, poprzez zakorzenioną zasadę cuis regio, eius lingua (łac. czyj kraj, tego język). We współczesnych realiach dla nowych państw powstałych po rozpadzie Jugosławii istotne jest posiadanie własnego państwa i języka narodowego. Jednakże języki narodowe - co pokazały powyższe przykłady - często są wymieszane (np. wskazany przykład puter/maslac, wariantywność języka bośniackiego przysparzająca ogromnych problemów jednoznacznego wskazania właściwej leksyki oraz całkowita tożsamość języka czarnogórskiego z serbskim), co tym bardziej utrudnia ich rozgraniczenie.

\section{BIBLIOGRAFIA}

Abc prijevodi $<$ http://www.abcprijevodi.hr/> [23.03.2015].

B o brow nick a M. 2006: Patologie tożsamości narodowej w postkomunistycznych krajach słowiańskich. Uwagi o genezie i transformacjach kategorii tożsamości, Kraków: Towarzystwo Autorów i Wydawców Prac Naukowych Universitas.

B ońk ow ski R. 2010: Stowianie środkowo południowi na przełomie XX i XXI wieku. Język-ReligiaNaród - Państwo, Katowice: Uniwersytet Śląski w Katowicach.

B rom P. 2007: Czarnogórski standard wobec różnicowania językowego poludniowej Stowiańszczyzny, Bielsko-Biała: Wydawnictwo Akademii Techniczno-Humanistycznej.

Bugarski R. 2005: Jezik i kultura, Beograd: Biblioteka XX veka.

B u gar s ki R. 2013: Jezička politika i jezička stvarnost u Srbiji posle 1991. godine, [w:] V. Požgaj Hadži (red.), Jezik između lingvistike i politike, Beograd: Biblioteka XX vek, 102.

Ci c hoń s k a M. 1994: Języki Słowian Południowych wobec rozpadu SFRJ (Czy Słowiańszczyźnie przybywa języków?), [w:] M. Blicharski, H. Fontański (red.), Wspótczesne tendencje rozwoju języków słowiańskich. Tom 1, Katowice: Wydawnictwo Uniwersytetu Śląskiego, 43-44.

Cze rw iń s k i M. 2005: Język-ideologia - naród. Polityka językowa w Chorwacji a język mediów, Kraków: Wydawnictwo „scriptum”. 
Czerwiński M. 2006: Kulturowe aspekty bośniacko-hercegowińskich języków wobec językowych narzędzi wyznaczania odrębności etnonarodowej, Socjolingwistyka 20,69.

Ho fman-Pianka A. 2000: Socjolingwistyczne aspekty współczesnego języka bośniackiego, Kraków: Wydawnictwo Radamsa.

Hrvatski jezični portal <http://hjp.novi-liber.hr/> [25.03.2015].

Is a k ovi ć A. 1997: Bosanski jezik, [w:] E. Tokarz (red.), Język wobec przemian kultury, Katowice: Wydawnictwo Uniwersytetu Śląskiego, 69.

J a r o s z e w i c z H. 2004: Nowe tendencje normatywne w standardowych językach chorwackim i serbskim, Opole: Wydawnictwo Uniwersytetu Opolskiego.

J e rg o vi ć M. 1999: Hrvatski prijevod srpskog filma „Rane” ili kako zapakirati isti nježnik u drugi tetra pak. MARŠ U SPORNI ORGAN! <http://govori.tripod.com/rane.htm> [23.03.2015].

Katnić-B a k aršić M. 2013: Bosanskohercegovačka sociolingvistička previranja, [w:] Požgaj Hadži V. (red.), Jezik između lingvistike i politike, Beograd: Biblioteka XX vek, 120.

Ko m a ti n a N. 2012: Jezik i identitet u Crnoj Gori, [w:] S. Perović (red.), Mi o jeziku, jeziko nama. Zbornik radova sa druge konferencije društva za primjenjenu lingvistiku (Podgorica, 23.10.2010), Podgorica: Društvo za primijenjenu lingvistiku Crne Gore, 169.

Kordić S. 2010: Jezik i nacionalizam, Zagreb: Durieux.

O c zk ow a B. 2003: Charakter zmian we współczesnym języku chorwackim, [w:] Z. Rudnik-Karwatowa (red.), Procesy innowacyjne w językach stowiańskich, Warszawa: Slawistyczny Ośrodek Wydawniczy oraz Towarzystwo Naukowe Warszawskie, 154.

Oc zk ow a B. 2011: Język chorwacki, [w:] B. Oczkowa, E. Szczepańska (red.), współpr. T. Kwoka, Stowiańskie języki literackie. Rys historyczny, Kraków: Wydawnictwo Uniwersytetu Jagiellońskiego, 294$-295,309$.

P a ň i ć T. 1999: Srpsko-hrvatski apsurdi. Titlovanje i tiltovanje, Vreme broj 1.

Paždjers ki D.-V., Chaci a E. 2014: Zarys fonetyki języka serbskiego. Szkic historyczny, dialekty, akcenty, Gdańsk: Wydawnictwo Uniwersytetu Gdańskiego.

P o p i ołe k B. 2011a: Język serbski, [w:] B. Oczkowa, E. Szczepańska (red.), współpr. Kwoka T., Stowiańskie języki literackie. Rys historyczny, Kraków: Wydawnictwo Uniwersytetu Jagiellońskiego, 259.

P op i ołe k B. 2011b: Język czarnogórski, [w:] B. Oczkowa, E. Szczepańska (red.), współpr. T. Kwoka, Stowiańskie języki literackie. Rys historyczny, Kraków: Wydawnictwo Uniwersytetu Jagiellońskiego, 275.

Požgaj Hadži V., Balazic Bulc T., Miheljak V. 2013: Srpskohrvatski jezik iz slovenske perspektive, [w:] Požgaj Hadži V. (red.), Jezik između lingvistike i politike, Beograd: Biblioteka XX vek, 39.

R a p a ck a J. 1997: O idei jugosłowiańskiej jako idei narodowej, [w:] M. Bobrownicka, L. Suchanek, F. Ziejka (red.), Współcześni Stowianie wobec własnych tradycji i mitów. Sympozjum w Castel Gandolfo 19-20 sierpnia 1996, Kraków: Towarzystwo Autorów i Wydawców Prac Naukowych Universitas, 47-48.

R is t ić J. 2012: Hrvatsko-srpsko titlovanje legalno ili glupo, <http://www.istmedia.rs/hrvatsko-srpsko-titlovanje-legalno-ali-glupo/> [23.03.2015].

Tą p o row sk a A. 2006: Język serbsko-chorwacki — jeden czy dwa języki?, [w:] I. Petrov (red.), Bałkany w oczach młodego czlowieka. Materialy z międzynarodowej naukowej konferencji studenckiej, Lódź, 28-29 kwietnia 2005 roku, Łódź: Wydawnictwo „Piktor”, 54-55.

Worldwide Translations $<$ http://www.worldwide.rs/ $>$ [23.03.2015].

Zakon o elektroničnim medijama, <http://narodne-novine.nn.hr/clanci/sluzbeni/2009_12_153_3740.html> [22.03.2015].

Zieliński B. 2006: Transformacja południowosłowiańskich idei narodowych na przełomie XX i XXI wieku, Sofia. Pismo filozofów krajów stowiańskich 6, 61. 


\section{SUMMARY}

„Mješavinu uspite“ or „,mešavinu sipatje“ — are translations and separate labels of food products really needed? The analyse of choosen examples

Keywords: Serbo-Croatian language, Bosnian language, Croatian language, Montenegro language, Serbian language.

This article shows and analyses the language differences in the region of former Yugoslavia. Language politics in the countries of former Yugoslavia is aimed to prove that differences really exist, that is why this research would like to show the fact that those differences are symbolical (example of translation from Croatian to Serbian and labels of food products). Four languages which came into being from Serbo-Croatian language family are still based on the New Shtokavian dialect and the differences are discernible only on lexical surface characteristic for region, not nation. The result of the analyses of those examples show that differences are artificially created because very often a word considered to be unique in one language exists in other languages too. During the analyses the comparative method was used. 